\title{
Off- Clamp nephron sparing minimally invasive surgery for multifocal tumors: experience of a case
}

\section{Cirugía preservadora de nefronas para tumores multifocales sin isquemia: experiencia de un caso}

\author{
José Francisco López-Verdugo, ${ }^{1}$ José Gustavo Arrambide-Herrera, ${ }^{1}$ Jaime Aviña-Magaña, ${ }^{1}$ \\ (iD) Fred Alain Montelongo-Rodríguez. ${ }^{2^{*}}$
}

Key words:

Renal cell cancer, nephron-preserving surgery, laparoscopy,

off-clamp

Autor de correspondencia: *Fred Alain Montelongo Rodríguez. Calle Madero S/N, Mitras Centro, Monterrey,

Universidad Autónoma de Nuevo León, Monterrey, Nuevo León. Correo electrónico: fred.montelongo@ gmail.com

\section{Abstract}

Description of the clinical case: 61-year-old female who presented to the outpatient clinic, asymptomatic and with an imaging study suggestive of multiple ipsilateral right kidney tumors as well as adrenal incidentaloma. The patient was treated with a laparoscopic partial nephrectomy of both renal tumors and adrenalectomy. Renal cell cancer nuclear grade 2 has been reported in the tumor of the upper pole, angiomyolipoma in the middle region of the kidney and cortical adenoma.

Relevance: Until now, the incidence of synchronous renal tumors at the time of diagnosis is unknown, likewise with new technologies and with greater surgeon's experience, nephron-preserving surgery has been proposed in multifocal renal tumors for the treatment of this type of tumors.

Clinical implications: There is a controversy and few reports where this type of tumors are treated with nephron-sparing surgery in multifocal tumors. So far in series of clinical cases this technique has been reported as safe and feasible in selected cases.

Conclusions: In expert hands and in particular cases, this technique seems to be a reproducible and safe procedure for the patient, thus ensuring that part of the renal unit is preserved, and good oncological results.

Citación: López-Verdugo J.F., Arrambide-Herrera J.G., Aviña-Magaña J., MontelongoRodríguez F.A. Off- Clamp nephron sparing minimally invasive surgery for multifocal tumors: experience of a case. Rev Mex Urol. 2021;81(3):pp. 1-6

\footnotetext{
${ }^{1}$ Instituto de Urología Robótica y Laparoscópica, Universidad de Monterrey, Nuevo León, México.

${ }^{2}$ Universidad Autónoma de Nuevo León, Hospital Universitario “Dr. José Eleuterio González”, Nuevo León, México.
}

Recibido: 15 de mayo de 2021 Aceptado: 30 de junio de 2021

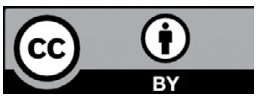




\section{Cirugía preservadora de nefronas para tumores multifocales sin isquemia: experiencia... López-Verdugo J. F., et al.}

\section{Resumen}

Descripción del caso clínico: Femenina de 61 años que se presenta a la consulta externa, asintomática y con estudio de imagen sugestivo de multiples tumoraciones renales derechas ipsilaterales asi como incidentaloma suprarenal. Se comienza abordaje de la paciente y se realiza una nefrectomía parcial laparoscópica de ambas tumoraciones renales más adrenalectomía. Se reporta cáncer de células renales grado nuclear 2 en la tumoración del polo superior, angiomiolipoma en la region media del riñon y adenoma cortical.

Relevancia: Hasta el momento se desconoce cual es la incidencia de tumoraciones renales sincrónicas al momento del diagnóstico, asi mismo con nuevas tecnologías y con la mayor experiencia del cirujano se ha propuesto la cirugia presevadora de nefronas en tumores renales multifocales para el tratamiento de este tipo de tumoraciones.

Implicaciones clínicas: Existe controversia y pocos reportes en donde se trata este tipo de tumoraciones con cirugía preservadora de nefronas en tumoraciones multifocales. Hasta el momento en revisiones y series

Palabras clave:

Cáncer de células renales, cirugía preservadora de nefronas, laparoscopia, sin isquemia de casos clínicos esta técnica se ha reportado como segura y factible en casos seleccionados.

Conclusiones: En manos expertas y en casos particulares, esta técnica pareciera ser un procedimiento reproducible y seguro para el paciente asegurando asi preservar la funcion de la unidad renal y buenos resultados oncológicos.

\section{Introduction}

Nephron sparing surgery has been used since late of the 20th century, this technique according to, American Urological Association and European Association of Urology, is recommended for the management of small renal mases. ${ }^{(1-3)}$ Reports of the first laparoscopic partial nephrectomy are from Winfield et al. in 1995 , today this technique is still a challenge for the urologist and requires a high level of expertise. ${ }^{(4)}$ The precise incidence of ipsi- lateral synchronous tumors is unknown, but there are case series and reviews that suggest that minimally invasive nephron sparing surgery for multifocal ipsilateral tumors is feasible and safe for patients who present with multiple tumors in the same renal unit. ${ }^{(5)} \mathrm{We}$ present 61-year-old women that presented as an outpatient clinic with imaging studies that suggest the finding of two ipsilateral renal tumors and an adrenal tumor. 


\section{Clinical Case}

A 61-year-old female presented as an outpatient clinic due to the incidental finding of a tumor in the right adrenal gland as well as synchronous tumors in the right kidney. At physical examination blood pressure was within normal parameters $110 / 70 \mathrm{mmHg}$. The patient denies episodes of macroscopic hematuria or involuntary weight loss. In addition, our patient informed that she felt well without any alteration, however, in a routine check-up, multiple tumors were found.

Laboratory workup reported a hemoglobin of $12 \mathrm{mg} / \mathrm{dL}(12-15.5 \mathrm{mg} / \mathrm{dL})$, Urinalysis demonstrated microscopic hematuria with 10 $\mathrm{rbc} / \mathrm{hpf}$, and urinary metanephrines 0.3 (> 1.3 positive test). Magnetic Resonance (Figure 1 and 2) showed two ipsilateral renal tumors, one at the upper pole of $3.5 \mathrm{~cm}$ and the other at the mid-portion of the kidney of $3 \mathrm{~cm}$, likewise an adrenal tumor of $1.5 \mathrm{~cm}$ was observed, normal chest x-ray.

Figure 1. Angiomyolipoma and adenoma (arrow)



Figure 2. Upper pole Renal Cell Cancer

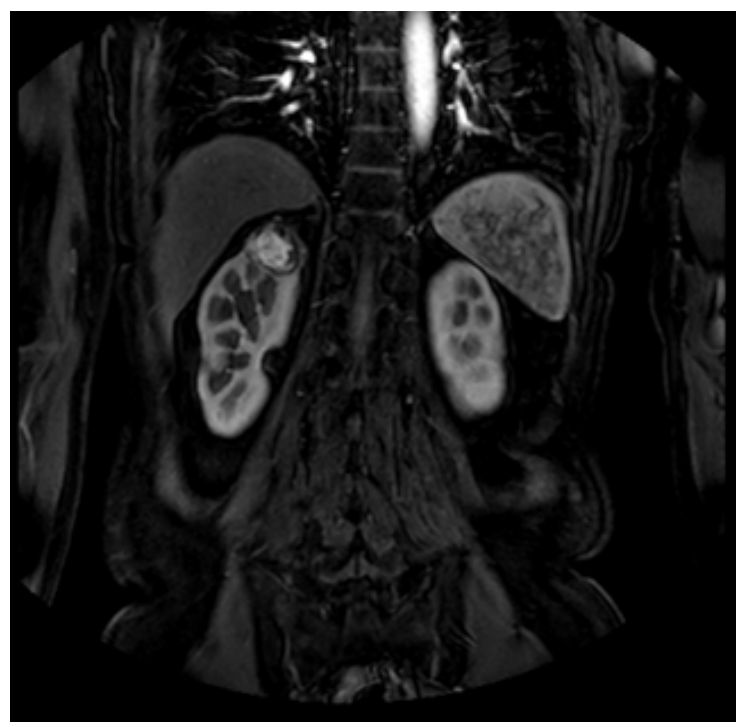

It was decided to perform laparoscopic partial nephrectomy of both renal tumors with a R.E.N.A.L. score of 4 for the upper pole tumor and a R.E.N.A.L. score of 5 for the tumor suggestive of angiomyolipoma in addition to adrenalectomy of the adrenal gland. The procedure was performed in 2 hours without ischemia and $500 \mathrm{ml}$ of intraoperative bleeding without complications. Patient had a good evolution and was discharged two days after surgery. Histopathology reported a cortical adenoma, angiomyolipoma and renal cell cancer nuclear grade 2 , with free negative margins.

\section{Discussion}

We present an interesting case and the first described in México according to the authors of the management of a patient with multiple ipsilateral tumors with a minimally invasive nephron-sparing surgery technique without ischemia. With this case report we demonstrate how this type of procedure is feasible and safe 
to carry out in those patients in whom it is desired to preserve an adequate renal function and oncological results, all this always and when it is performed in the hands of an expert surgeon and in a well selected patient.

Sporadic multifocal renal disease has an incidence of 6 to $25 \%$ in population with non-hereditary renal cancer. ${ }^{(6)}$ Bilaterality, multifocality, and early age are characteristics that patients with hereditary kidney cancer diagnosis have, characteristics our patient does not present. ${ }^{(7)}$ In addition, our patient lacks clinical characteristics of a classical Von Hippel-Lindau syndrome like positive family history, hemangioblastomas of the brain, retina, and spinal cord, pheochromocytoma, paraganglioma, pancreatic cysts, and neuroendocrine tumors, making the diagnosis of this syndrome very unlikely. ${ }^{(8)}$

The decision of removing the adrenal gland was made because there are reports that up to $75 \%$ of patients with an incidentaloma of the adrenal gland in association with renal tumor, like the one presented in our patient, it could be of metastatic origin. ${ }^{(9,10)}$ Moreover, we made the decision to perform partial nephrectomy of both tumors. The upper pole tumor has a supportive image of a malignant lesion, with optimal dimensions to perform this procedure. (11) The other tumor suggestive of an angiomyolipoma, which is a tumor capable of growing and bleeding as it grows, we decided to remove it to reduce possible complications in the future and thus ensuring that an acceptable kidney function. ${ }^{(12)}$

According to Wang et al. ${ }^{(13)}$ this type of presentation of multifocal tumors could be treated with good oncological results through a retroperitoneoscopic procedure, however, we did not found studies where patients with ipsilate- ral renal tumors were treated by this approach. It is important to take into account that multifocal ipsilateral renal diseases have 5 times more risk of having contralateral recurrence. (14) So, it is of the greatest importance to bear in mind the characteristics of the aforementioned tumors and the high risk of recurrence, to be able to make the decision to perform a nephron sparing surgery. Oncological outcomes seem not to be altered when performing nephron sparing surgery neither bilateral nor ipsilateral multifocal renal masses in terms of cancer-specific survival outcomes. ${ }^{(15,16)}$

This case adds to the review presented by Ginzburg et al. ${ }^{(5)}$ where they mentioned that there is evidence of 50 patients who were managed with minimally invasive nephron-sparing surgery in multiple ipsilateral tumors, demonstrating how this technique can be reproducible in these types of patients, such as the one we present. An interesting detail that differentiates us from the cases presented in this review is the ischemia time, taking into account that in our case the ischemia time was zero. This technique was reproducible because we have two tumors smaller than $7 \mathrm{~cm}$, which, according to the review by Kreshover et al. ${ }^{(17)}$ makes the procedure feasible without having a significant risk of bleeding and so the need for blood transfusion, also could help preserve kidney function even more considering that we are removing two renal masses without applying ischemia to the renal unit; this is an interesting detail that should be taken into account for future research in the setting of multifocal renal tumors.

There are reports of treatments through robotic surgery in patients with bilateral and ipsilateral multifocal tumors, the first of them was the one reported by Boris et al. ${ }^{(18)}$ where 
Cirugía preservadora de nefronas para tumores multifocales sin isquemia: experiencia... López-Verdugo J. F., et al.

$70 \%$ of its patients had some genetic syndrome. The one that most resembles our study by population studied, without any genetic syndrome, is the one presented by Laydner et al. ${ }^{(19)}$ where it was concluded in a short-time evaluation that robotic nephron sparing surgery for multiple ipsilateral tumors was feasible and also it could be performed without ischemia in patients candidates for this technique for example in exophytic tumors. In addition, in situations where the clamping of the renal artery can cause kidney damage, such as in solitary kidney, renal failure or multiple renal masses, the surgeon should consider the option of performing a procedure without ischemia as mentioned by Anderson et al. ${ }^{(20)}$

As the study presented is a case report, we recognize that the level of evidence is low, however it is important to make our experience known so that this case can serve as a basis for future research.

\section{Conclusion}

We are faced with an unusual finding of multiple kidney tumors in addition to one adrenal gland tumor. This case in which we perform nephron-sparing surgery without ischemia is the first report in México and represents a therapeutic challenge that up to now, according to reviews and case series, has given good oncological and functional results, confirming that this procedure can be used in well-selected patients. We must take this case as a reference for future research with specific guidelines and criteria to establish which patients would be the ideal candidates for this minimally invasive surgical procedure.

\section{Financial disclosure}

No financial support was received in relation to this article.

\section{Conflict of interest}

The authors declare that there is no conflict of interest.

\section{CRediT Taxonomy}

Critical revision of the Manuscript: José Francisco López-Verdugo, José Gustavo Arrambide-Herrera, Jaime Aviña-Magaña.

Data acquisition: José Gustavo Arrambide-Herrera, Jaime Aviña-Magaña, Fred Alain Montelongo-Rodríguez.

Drafting Manuscript: Fred Alain Montelongo-Rodríguez

\section{References}

1. Wells S. Successful Removal of Two Solid Circum Renal Tumours. Br Med J. 1884;1(1216):758758. doi: 10.1136/bmj.1.1216.758

2. Campbell S, Uzzo RG, Allaf ME, Bass EB, Cadeddu JA, Chang A, et al. Renal Mass and Localized Renal Cancer: AUA Guideline. J Urol. 2017;198(3):520-9. doi: 10.1016/j. juro.2017.04.100

3. Ljungberg $\mathbf{B}$, Albiges L, Abu-Ghanem Y, Bensalah K, Dabestani S, Fernández-Pello S, et al. European Association of Urology Guidelines on Renal Cell Carcinoma: The 2019 Update. Eur Urol. 2019;75(5):799-810. doi: 10.1016/j. eururo.2019.02.011 


\section{Cirugía preservadora de nefronas para tumores multifocales sin isquemia: experiencia... López-Verdugo J. F., et al.}

4. Winfield HN, Donovan JF, Godet AS, Clayman

RV. Laparoscopic Partial Nephrectomy: Initial Case Report for Benign Disease. Journal of Endourology. 1993;7(6):521-6. doi: 10.1089/ end.1993.7.521

5. Ginzburg S, Uzzo RG, Kutikov A. The Role of Minimally Invasive Surgery in Multifocal Renal Cell Carcinoma. Curr Urol Rep. 2012;13(3):20210. doi: 10.1007/s11934-012-0251-3

6. No authors listed. NIH state-of-the-science statement on management of the clinically inapparent adrenal mass ('incidentaloma'). NIH Consens State Sci Statements. 2002;19(2):1-25.

7. Gittens PR, Solish AF, Trabulsi EJ. Surgical management of metastatic disease to the adrenal gland. Semin Oncol. 2008;35(2):172-6. doi: 10.1053/j.seminoncol.2007.12.006

8. Van Poppel H, Da Pozzo L, Albrecht W, Matveev V, Bono A, Borkowski A, et al. A prospective, randomised EORTC intergroup phase 3 study comparing the oncologic outcome of elective nephron-sparing surgery and radical nephrectomy for low-stage renal cell carcinoma. Eur Urol. 2011;59(4):543-52. doi: 10.1016/j. eururo.2010.12.013

9. Fernández-Pello S, Hora M, Kuusk T, Tahbaz R, Dabestani S, Abu-Ghanem Y, et al. Management of Sporadic Renal Angiomyolipomas: A Systematic Review of Available Evidence to Guide Recommendations from the European Association of Urology Renal Cell Carcinoma Guidelines Panel. Eur Urol Oncol. 2020;3(1):5772. doi: 10.1016/j.euo.2019.04.005

10. Kreshover JE, Kavoussi LR, Richstone L. Hilar clamping versus off-clamp laparoscopic partial nephrectomy for $\mathrm{T} 1 \mathrm{~b}$ tumors. Curr Opin Urol. 2013;23(5):399-402. doi: 10.1097/ MOU.0b013e3283632115 